\title{
A POA Theory-based Network Teaching Mode for English Course in Higher Vocational College
}

\author{
https://doi.org/10.3991/ijet.v17i01.28459 \\ Jinrong Shu \\ Hunan Railway Professional Technology College, Zhuzhou City, China \\ 1519500014 de.gzhu.edu.cn
}

\begin{abstract}
As the world economy develops quickly, more and more overseas-funded enterprises have swarmed into the markets of different countries. Therefore, English teaching is very essential because English is the main communication language. However, students in higher vocational colleges with poor English foundation, weak learning ability, and low enthusiasm and interest in English learning, seriously affecting students 'English practical ability and their employment. Despite the adoption of Internet information technology in some schools to carry out English teaching, the teaching content is limited to textbooks and instructed by single teaching methods, which is ineffective to improve students' English practical ability. In view of this, in order to enhance the English classroom teaching effect in higher vocational colleges, improve students' English learning and practical ability, stimulate their interest in English learning and initiative, a POA (production-oriented approach) theory-based network teaching mode was introduced in this paper. Firstly, based on POA teaching theory, the application in English teaching in higher vocational college was analyzed, and then student independent learning evaluation system was designed using AHP. In order to promote students' autonomous learning, SPOC mode was also introduced to provide students with a wealth of learning resources. Practical teaching results have shown that the POA theory-based network teaching mode can yield significant effects on improving students' English practical ability, stimulating students' interest and enthusiasm in English learning.
\end{abstract}

Keywords-POA theory, network teaching, evaluation system, vocational English

\section{Introduction}

Higher vocational colleges as the major form of higher education and an important component of vocational education undertake the task of cultivating talents with certain higher education knowledge professional skills and expertise, rather than outputting senior scientific research talents, so that application technology practices should be emphasized during teaching [1]. English is an essential course in the curriculum settings of higher vocational colleges. With the high-speed development of the global economy, more and more transnational enterprises have set up branches in different countries, which will be very beneficial for higher vocational students if they have mastered high 
English professional skills [2]. However, higher vocational students as a special group with poor academic scores in high school are even "neglected" and are forced to enter higher vocational schools because they cannot be admitted to undergraduate schools. With a relatively weak English foundation, lack of research spirit, they often muddle along when learning and have no clear learning goals and strong learning motivation. They are obsessed with games, network, etc., without strong interest in learning [3]. Moreover, after entering higher vocational colleges, with the sharply reduced test pressure, their English learning enthusiasm declined greatly. Therefore, how to improve higher vocational students' enthusiasm of English and enhance English teaching effect in higher vocational colleges is an important issue that higher vocational colleges should urgently addressed at present.

With the high-speed development of Internet information technology, online teaching mode has been widely applied to various courses, including higher vocational English course. However, the teaching course content is limited to textbooks, teaching method is single, without teacher-student interaction. In terms of the teaching effect, there exists serious learning-practice divergence phenomenon. No combination between English learning and ability training leads to students' poor English application ability. They cannot meet business talent requirements, which is not conducive to students' development. Therefore, in order to improve higher vocational English teaching effect, and enhance students' English level, a POA-based network teaching mode was proposed in this paper. The innovation of this study is mainly reflected in three aspects. Firstly, when designing higher vocational English teaching mode, information technology was integrated with production-oriented classroom and applied to higher vocational English course teaching. Secondly, SPOC teaching mode was designed according to specific learning condition to satisfy students' employment needs and substantially enhance students' English application capabilities. Thirdly, considering that English ability requires long-term accumulation and students' certain autonomous learning ability. In view of this, a POA-based (output-oriented) student autonomous evaluation system was established in this study to comprehensively evaluate higher vocational students' English learning effect.

\section{State of the art}

To enhance the teaching effect, a lot of scholars have studied the improvement of teaching modes, including the models of English classroom teaching, among which production-oriented approach and network teaching model have yielded mature research theories. Regarding the application of network teaching mode in classroom, scholars Hendriks et al. [4] studied large-scale open network course, namely, the application of MOOC teaching mode in medical class, and they believed that it is necessary to use the MOOC teaching model to reshape medical classroom teaching from perspective of enhancing social cognition and students' practical application capabilities, it is necessary to pay attention to individual teaching mode, rather than group teaching, objectivism. Kam et al. [5] also studied online open course MOOC teaching mode, and believed that it is necessary to effectively utilize Internet information technology during 
specific teaching mode design, so as to provide students with flexible and personalized learning experience for students according to the course characteristics based on MOOC related experience design. Designed to. Rajiv et al. [6] elaborated the importance of network teaching mode during the COVID-19 epidemics, and designed a specific network teaching mode. They believed that to obtain good teaching effect, it is necessary to pay attention to the interactivity while considering students' diversity and providing students with a wealth of learning resources. A lot of Chinese scholars have studied the application of network teaching mode in English classroom teaching. For example, Han [7] studied the application of blended teaching mode in college English classroom teaching, and believed that blended learning method fully integrating traditional classrooms teaching mode with online learning model is very important to enhance English teaching efficiency and level. It is found by the author through research that blended teaching mode can diversify college English, mobilize student learning initiative and interest, and supplement the traditional classroom teaching mode. Sun et al. [8] believed that with the development of Internet information technology and new media, students have realized English independent learning. However, the authors found that the existing network teaching mode lacks the assessment of students' comprehensive capabilities and lacks process assessment. Therefore, it is proposed that colleges and universities should improve process assessment of network teaching model, so as to diversify students' autonomous learning evaluation. It is also necessary to emphasize students 'subjectivity in English learning, thus truly enhancing students' autonomous learning competence.

Regarding the application of the production-oriented approach in English classroom teaching, $\mathrm{Hu}$ [9] believed that the production-oriented approach has changed students' passive English learning to active English learning, and effectively enhanced the learning-practice divergence phenomenon, and realized the combination of learning and application. The author also believes that the production-oriented teaching mode has fully utilized limited class time and obtained better teaching effect. James [10] studied the teaching mode from the learning effectiveness view, and believed that the mobility should be an important indicator to measure the effectiveness of teaching mode, that is, it is determined by whether students can effectively apply language skills and social capabilities to actual cases. From this perspective, production-oriented approach is a more effective teaching mode. $\mathrm{Li}$ [11] believed that production-oriented approach is a socialist English teaching model with Chinese characteristics. After studying this model in the English flipping class, the author designed higher vocational English flipped classroom from driven, facilitated and evaluation perspectives, so as to improve higher vocational students' English learning ability. Wang [12] introduced the production-oriented approach into English micro-course teaching, and believed that this mode conformed to the development trend of English education, greatly helped improve students' English practical ability. Therefore, according to the difficulties in comprehensive English teaching, the author specifically designed the teaching mode and applied it to multiple teaching units such as import, reading, grammar, vocabulary. The results showed that this mode has substantially improved students' participation, enhanced the comprehensive English teaching effect. Zhang [13] constructed a new teaching mode for graduate English course "Academic English" under the guidance of four major hypotheses 
of production-oriented approach. Through research, the author found that the new teaching mode has clarified students' learning goal, strengthened students' English learning enthusiasm, and also facilitated students' extracurricular learning, and well supplemented classroom learning. Meanwhile, this model has effectively enhanced students' academic English level, especially their academic collaborative ability, foreign literature translation skills, English reading competence. The teaching effect of graduate course "Academic English" has greatly improved. Xiao [14] believed that production-oriented approach has emphasized the dominant role of teachers in English teaching, with great significance to enhance students' learning enthusiasm and improve learning effects. In view of this, based on production-oriented approach, according to the output-driven, input-enabled evaluation teaching process, a cloud platform was established for higher vocational English teaching combining online and offline teaching model. With higher vocational English course "Health" theme as the specific example, the study also explained how to carry out English teaching through production-oriented approach.

Through a summary of above related research, it can be seen that a lot of domestic and foreign scholars have conducted research on network teaching mode, POA teaching mode, etc. However, only a very few scholars studied the integration of the two. In fact, integration of POA teaching mode and SPOC network teaching mode can truly realize stratified teaching, which conform to the complicated characteristics of higher vocational English education, and it will also promote students' deep learning, which has very important significance to strengthen higher vocational students' learning enthusiasm.

\section{POA-based network teaching mode for higher vocational college English course}

\subsection{Application of POA in teaching}

Production-oriented approach (POA) [15] is a teaching theory proposed by foreign language educator Wen Qiufang based on "output-driven - input-enabled hypothesis". By referring to the output hypothesis, input hypothesis, and interactive assumptions, the teaching theory including three major systems of teaching concept, teaching hypothesis, and teaching process was ultimately developed (Figure 1).

The entire POA teaching mode including three parts of teaching concept, teaching hypothesis, and teaching process finally establishes output-driven, input-enabled evaluation. Output-driven means teachers assign "output" task to the students, requiring students to complete independently. Input-enabled requires teachers to know whether students can independently complete and provide a certain guidance, and the evaluation means to preset indicators for "output" evaluation and to actively introduce teachers' reviews and students' mutual evaluation.

When applying POA teaching mode in higher vocational English teaching, at the core of actual teaching task, based on special teaching content, according to higher vocational students' interest in English, different unit courses are designed, so that higher 
vocational students can carry out English learning autonomously, independently complete relevant tasks and apply what they have learned to the actual life. Specifically, in the POA-based higher vocational English teaching mode, output refers to the English learning goal of higher vocational students, who can choose corresponding content from the input perspective for intensified study and carry out autonomous learning according to the requirements of output. Also, the evaluation of students can help teachers carry out corresponding teaching according to students' real-time states, so that students can master more knowledge.

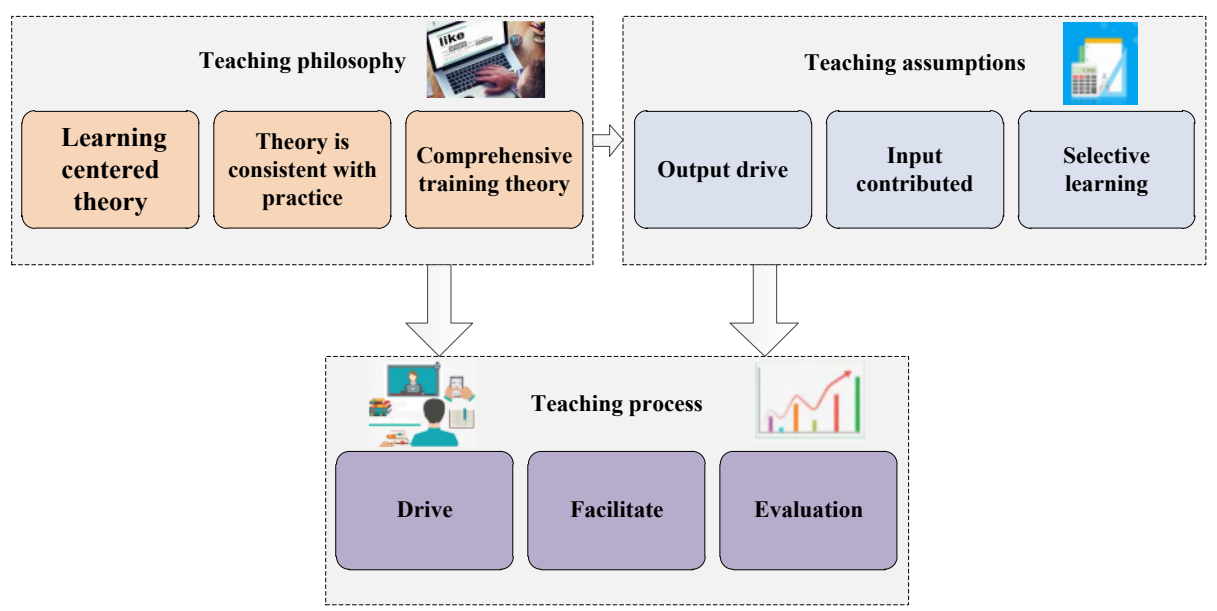

Fig. 1. POA teaching theory system

\subsection{POA-based students' autonomous evaluation}

In POA teaching mode, evaluation is an important part. In this section, the students' autonomous evaluation model will be established according to will the current English learning situation among higher vocational students.

1. Create fuzzy sets

Define the first-level index set $\mathrm{F}$ and weight set $\mathrm{A}$, that is:

$$
F=\left(f_{1}, f_{2}, \ldots f_{i}\right), A=\left(a_{1}, a_{2}, \ldots a_{i}\right), \text { where, } \sum_{i=1}^{i} a_{i}=1
$$

Define the second-level index set $f_{i}$ and weight set $a_{i}$, that is:

$$
f_{i}=\left(f_{i 1}, f_{i 2}, \ldots f_{i m}\right), a_{i}=\left(a_{i 1}, a_{i 2}, \ldots a_{i m}\right), \text { where, } \sum_{j=1}^{m} a_{i j}=1
$$

Define the second-level index set $f_{i j}$ and weight set $a_{i j}$, that is: 


$$
f_{i j}=\left(f_{i j 1}, f_{i j 2}, \cdots, f_{i j n}\right), f_{i j}=\left(f_{i j 1}, f_{i j 2}, \cdots, f_{i j n}\right) \text {, where, } \sum_{k=1}^{n} a_{i j k}=1
$$

Define students' autonomous evaluation index fuzzy set Q, the index will be eventually expressed by score points, of which 95 points: excellent; 85 points: good; 70 points: pass; 55 points: basically pass, 45 points: poor, specifically:

$$
Q=\left(q_{1}, q_{2}, \cdots, q_{s}\right)
$$

\section{Acquire fuzzy information}

When applying POA teaching mode, students' autonomous learning evaluation involves students' self-evaluation and teachers' comments on students, using the scoring method of excellent, good, pass, basic pass, poor. After the scoring, relevant fuzzy information set can be obtained according to FAHP and Delphi method.

3. Establish students' autonomous valuation system based on fuzzy information

When establishing student's autonomous evaluation system, FHP method will be used, so the evaluation operation process of the three levels is as follows:

$$
R_{i j}=A_{i j}^{S} * R_{i j}^{S}
$$

Meanwhile, $R_{\mathrm{ij}}^{\mathrm{S}}$ is the combination of a series of evaluation indexes, which satisfies:

$$
R_{i j}^{S}=\left[R_{i j 1}^{S}, R_{i j 2}^{S}, \ldots, R_{i j k}^{S}\right]^{T}
$$

Corresponding weight set also satisfies:

$$
A_{i j}^{S}=\left[A_{i j 1}^{S}, A_{i j 2}^{S}, \ldots, A_{i j k}^{S}\right]^{T}
$$

Therefore, a fuzzy comprehensive evaluation matrix of teachers on an index can be obtained, expressed as $\mathrm{n}$. Meanwhile, in order to reduce the impact of teachers' subjective factors on the evaluation results of students, the overall credibility can be obtained through the network system according to the comprehensive evaluation result of each teacher, thus further obtaining the fuzzy set of credibility of the teacher's evaluation on students' autonomous learning, that is:

$$
C_{i j}^{S}=\left(c_{i j 1}, c_{i j 2}, \ldots, c_{i j k}\right)
$$

Therefore, $\mathrm{n}$ is the comprehensive evaluation result of the teacher's evaluation on students' autonomous learning:

$$
\begin{gathered}
R_{i j}^{\prime}=C_{i j}^{S} * R_{i j}^{S} \\
R_{i j}^{S}=\left(\frac{R_{i j 1}^{\prime}}{\sum_{k=1}^{k} R_{i j k}^{\prime}}, \frac{R_{i j 2}^{\prime}}{\sum_{k=1}^{k} R_{i j k}^{\prime}}, \ldots, \frac{R_{i j K}^{\prime}}{\sum_{k=1}^{k} R_{i j k}^{\prime}}\right)=\left(R_{i j 1}, R_{i j 2}, \ldots, R_{i j K}\right)
\end{gathered}
$$


In addition, in order to ensure the credibility of the fuzzy comprehensive evaluation result, consistency test of the evaluation system is required, usually using CI:

$$
C I=\frac{\lambda_{\max }-n}{n-1}
$$

Where, $\lambda_{\max }$ satisfies:

$$
\lambda_{\max }=\sum \frac{(A W)_{i}}{n W_{i}}
$$

Generally, the larger the CI value, the poorer consistency of judgment matrix. If CI $=0$, then the judgment matrix is completely consistent. Usually, the first or second order judgment matrix is often completely consistent. For a better understanding of the consistency of the judgment matrix, $\mathrm{CR}$ index is often used to determine the consistency, specifically:

$$
C R=\frac{C I}{R I}
$$

Where, CR is also known as random consistency, while RI is average random consistency index.

\subsection{POA combined SPOC teaching mode for higher vocational college English course}

To facilitate higher vocational students' autonomous learning, SPOC (online classroom) teaching mode was also introduced, which perfectly undertakes higher vocational English online teaching work and supplements traditional teaching model. Specifically, POA + SPOC teaching mode follows the teaching process of "driven-enabledevaluation" s of POA theory, three links under coordinated operation. Its implementation process is shown in Figure 2.

When applying the teaching mode, in the driven link, it requires higher vocational college teachers to combine students' learning conditions and teaching objectives to assign English tasks to students, and require students to complete independently. In the enabled link, higher vocational English teachers know students' completion progress, provide certain guidance and recommendations accordingly. In the evaluation link, higher vocational English teachers need to comment on students' task completion, and encourage students' self-evaluation and mutual evaluation. In POA + SPOC teaching mode, teachers value autonomic learning right, which does not mean laissez-faire. The whole teaching process is still controllable, especially for higher vocational college students who attach more importance to professional English related to their own careers. Therefore, English teaching should emphasize application and mobilize students' enthusiasm by carrying out different forms of teaching activities while emphasizing the role of learning. Teachers should provide necessary assistance for students' reasonable learning to improve their actual learning efficiency. As can be seen from Figure 3, the 
teacher sets up classroom interaction link using POA teaching method to improve students' actual application ability. For students' application of knowledge, the focus lies in students' learning professional vocabulary knowledge in practice, getting familiar with their vocational English oral expression, practicing while learning, and applying English knowledge to study and life. In this study, the teaching activities are designed with actual occupational scene task as the core content based on special teaching content and students' interest in English course. To strengthen their English professional literacy, students continue to study and voluntarily engage themselves in learning English knowledge, fulfill academic task, and apply what they have learned to actual practice.

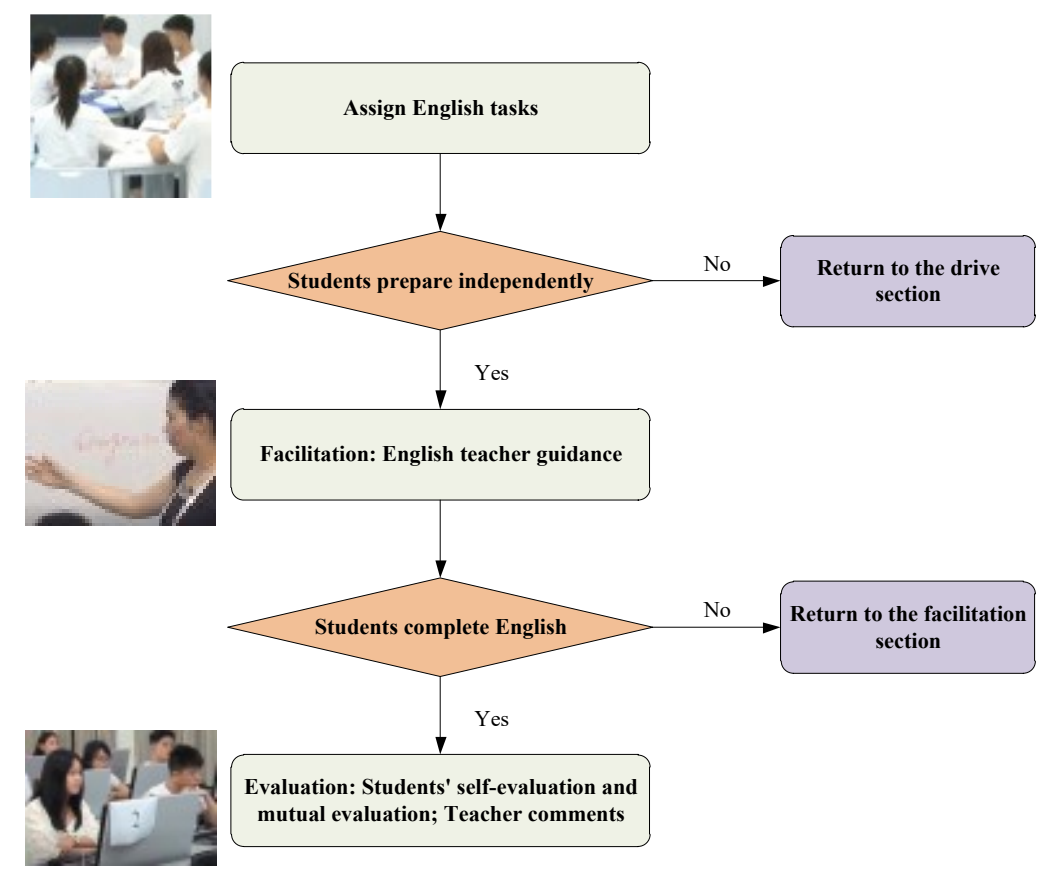

Fig. 2. The implementation of OA combined SPOC teaching mode for higher vocational college English teaching

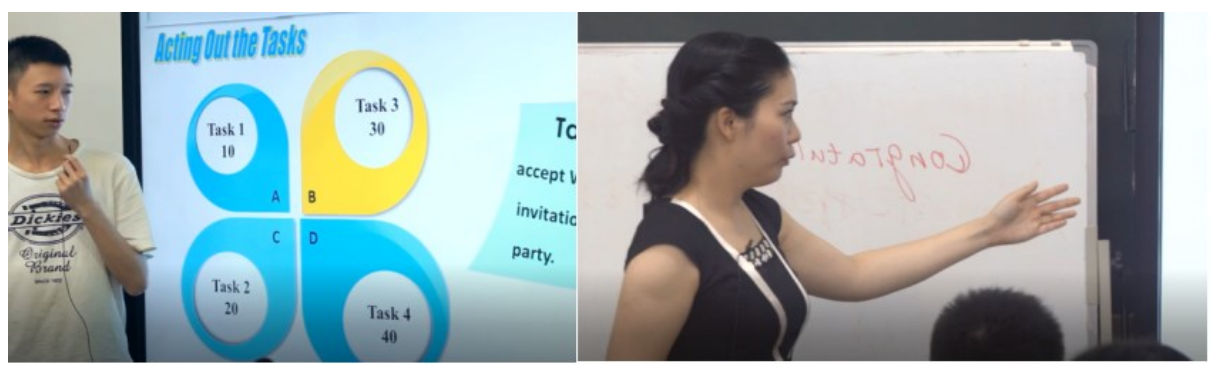

Fig. 3. Classroom interaction link display set by teacher according to POA teaching mode 
It can be seen from vocational English application classroom based on POA teaching method that output can better drive English learning than input in teaching activities, and output-driven can promote students to apply occupational vocabulary in practice and stimulate their interest in learning new vocabulary. In a hypothetical occupational situated learning environment, teachers emphasize to guide students' discussion and thinking, which can help students deepen their understanding of their knowledge, timely discover their weaknesses and then pay attention to pre-class preview and afterclass review. Students can continuously process and output new vocabulary information during active classroom participation, constantly improve their knowledge, better master English vocabulary, grammar, and enhance their language expression competence.

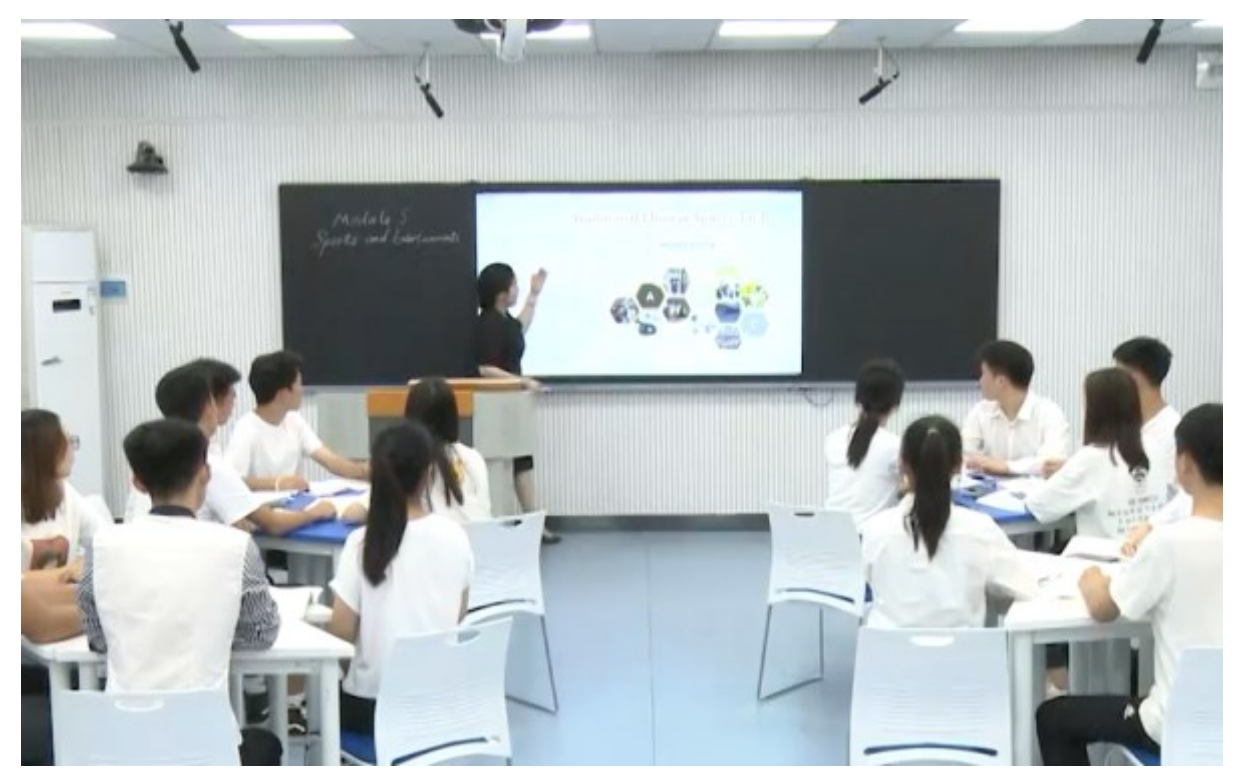

Fig. 4. Vocational English application classroom based on POA teaching mode

In the meantime, teachers can also manage the class, check learning materials and formulate various classroom activity contents on the learning platform before class and after class. It is feasible to make use of mobile learning platforms such as computers and mobile phones to help students carry out autonomic learning, which can be used as teachers' mobile teaching platforms at the same time. Teachers can release teaching resources on the computer, integrate international new knowledge related to student career into English teaching for the enrichment of classroom content, expand the teaching content, and introduce more vivid teaching content to classroom teaching for the enhancement of students' learning efficiency. 


\section{$4 \quad$ Teaching example and effect}

\subsection{Teaching example}

The application of POA-based network course teaching mode in higher vocational English course can be divided into three stages: output-driven (before-class preparation task stage), input-enabled (in-class effect verification) and evaluation. The teaching mode as shown in Figure 5:

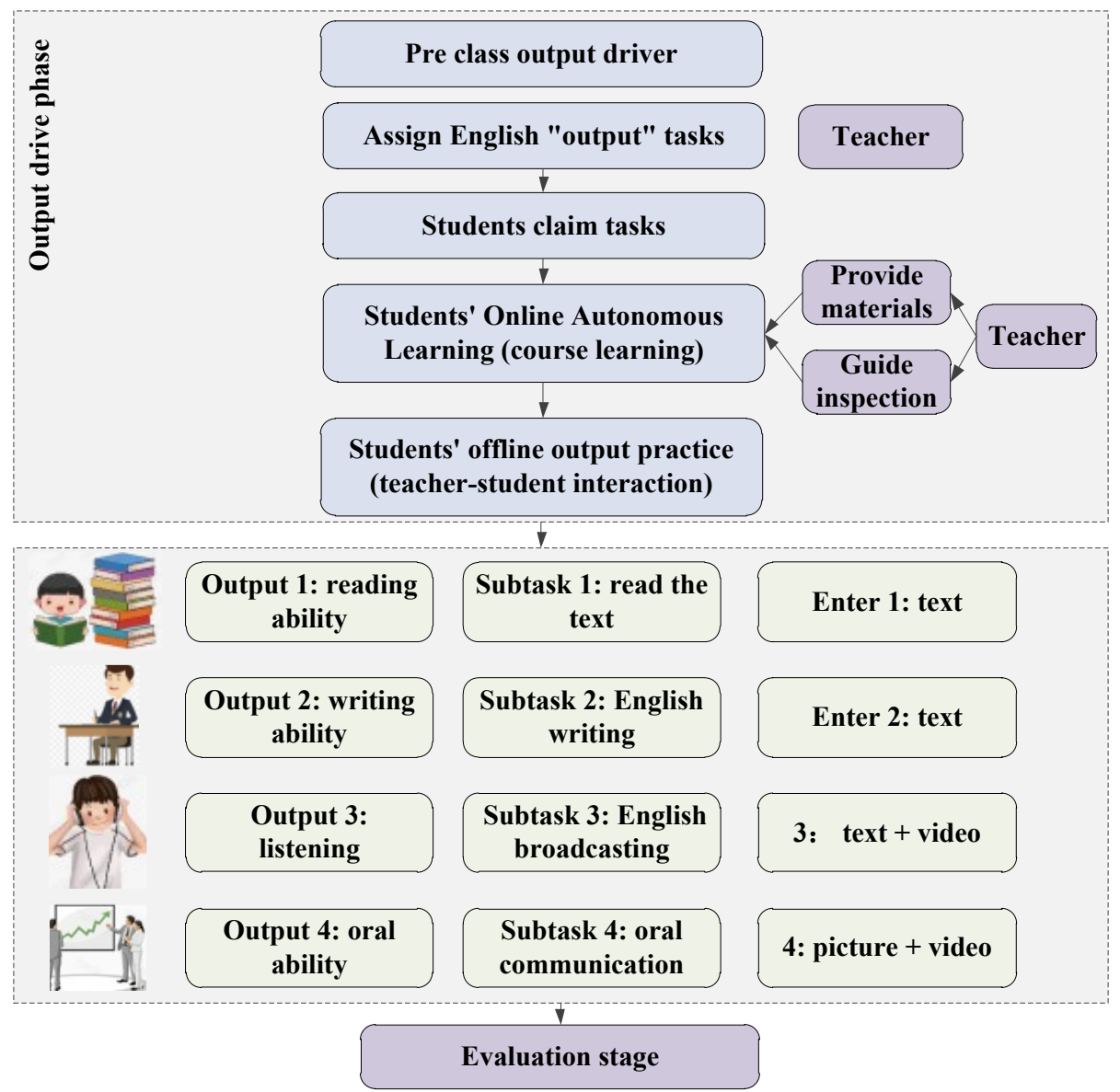

Fig. 5. POA-based network teaching mode for higher vocational college English course

At the output-driven stage, English teachers should design different units of English textbooks into different scenarios in accordance with the teaching outline and the cultivation goals of higher vocational colleges, set different output tasks in different scenarios, ask students to complete these tasks. Then, students carry out network independent learning based on the learning materials and instruction information assigned 
by the teacher (input). In order to complete the learning task, students can also discuss with teacher and other students in the classroom. At the input-enabled stage, English teachers should check different results of output tasks, and provide guidance for students' problems. For example, to enhance students' reading ability, English teachers can check students' text reading competence and instruct their translation and grammar until the completion of the output tasks. However, in the input link, teachers are required to focus on guiding students to output appropriate input materials in the classroom. For example, in this study, the teacher's input content has an important impact on students' after-class vocabulary and grammar learning. Corresponding teaching activities are designed mainly to teach students learning methods and content. Therefore, the design of classroom teaching activity is very important. Figure 6 shows the teaching activity link of POA-based teaching mode in English course.

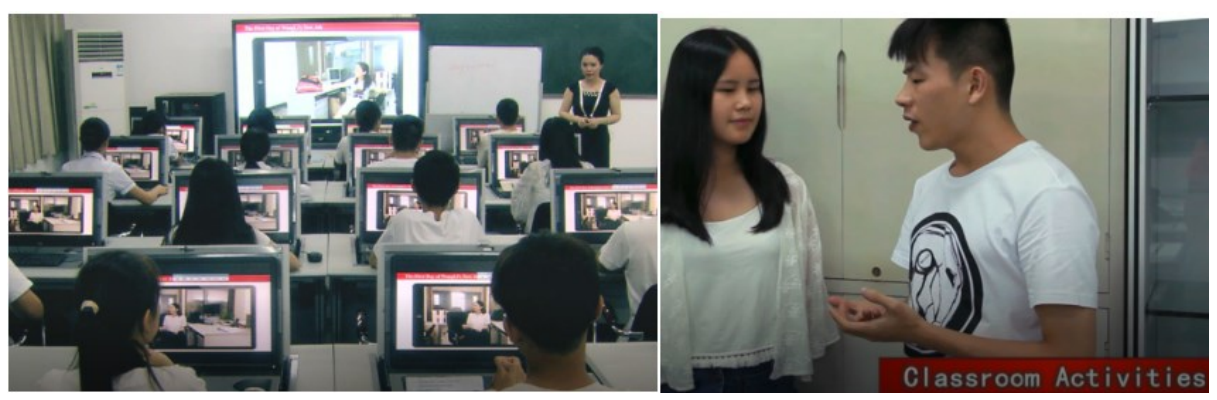

Fig. 6. Teaching activity link display of POA-based teaching mode in English course

This study has found that in teaching activities, there is an English learning difficulty involving a large number of new vocabularies, which are difficult for students to learn and memorize. So, the teacher can evaluate the content of students' discussion before class and then enlighten students to establish the structure of new knowledge, and provide assistance for them to learn new vocabularies, promote students to develop vocabulary language. When carrying out targeted college English vocabulary teaching, teachers should ask students to fully discuss their own difficulties and issues, and teachers input knowledge appropriately to help them consolidate knowledge.

When applying the teaching mode in higher vocational English course, this course, an essential stage is the teaching evaluation stage, which includes student self-evaluation, student mutual evaluation and teacher reviews. Among them, students' self-evaluation means that they evaluate their own English learning effect, learning interest, learning harvest, etc., and students' mutual evaluation refers to the evaluation of other students in learning efficiency, learning enthusiasm, and teachers' reviews refer to English teachers' evaluation on students' English reading, writing, listening, speaking, as well as the evaluation of students' autonomous learning condition. 


\subsection{Teaching effect}

In order to test above design, that is, the application effect of POA-based online teaching mode in higher vocational English course, a teaching practice was conducted in higher vocational English classrooms from March - July 2021, and a questionnaire survey was conducted on the formative evaluation in the three pilot classes. A total of 134 students from three classes were included in the survey.

The questionnaire survey was conducted to know higher vocational students' satisfaction with POA-based online course teaching mode from five aspects: satisfaction with teaching method, satisfaction with case teaching, satisfaction with classroom interactive teaching, satisfaction with requirements for teaching content combined with practice, and satisfaction with evaluation system. The satisfaction results are as shown in Table 1:

Table 1. Students' satisfaction with the teaching mode

\begin{tabular}{|l|c|c|c|c|c|}
\hline \multicolumn{1}{|c|}{ Item } & $\begin{array}{c}\text { Very } \\
\text { satisfied }\end{array}$ & $\begin{array}{c}\text { Relatively } \\
\text { satisfied }\end{array}$ & $\begin{array}{c}\text { Relatively } \\
\text { unsatisfied }\end{array}$ & $\begin{array}{c}\text { Very } \\
\text { unsatisfied }\end{array}$ & waiver \\
\hline Satisfaction with teaching method & $24.36 \%$ & $47.25 \%$ & $28.12 \%$ & $0.27 \%$ & $0.00 \%$ \\
\hline Satisfaction with case teaching & $31.90 \%$ & $49.09 \%$ & $18.18 \%$ & $0.11 \%$ & $0.72 \%$ \\
\hline Satisfaction with classroom interactive teaching & $29.89 \%$ & $51.25 \%$ & $17.19 \%$ & $1.67 \%$ & $0.00 \%$ \\
\hline $\begin{array}{l}\text { Satisfaction with requirements for teaching } \\
\text { content combined with practice }\end{array}$ & $32.14 \%$ & $50.89 \%$ & $16.97 \%$ & $0.00 \%$ & $0.00 \%$ \\
\hline Satisfaction with evaluation system & $21.06 \%$ & $41.91 \%$ & $31.89 \%$ & $5.14 \%$ & $0.00 \%$ \\
\hline Overall & $27.87 \%$ & $48.08 \%$ & $22.47 \%$ & $1.44 \%$ & $0.14 \%$ \\
\hline
\end{tabular}

It can be seen from results shown in Table 1, 75.95\% of students are satisfied with the POA-based network course teaching mode, among which they are most satisfied with requirements for teaching content combined with practice, accounting for $83.03 \%$, indicating that the teaching mode better suits higher vocational students' practice needs, and benefits a lot for their employment. At the same time, $81.14 \%$ of students are satisfied with classroom interactive teaching, and $80.99 \%$ of students are satisfied with case teaching. In addition, the satisfaction of teaching method and evaluation system also exceeds $70 \%$, indicating that the POA-based network teaching mode is effective in higher vocational English teaching.

The effectiveness of POA-based network course teaching mode was analyzed by analyzing the satisfaction of students' autonomous learning effects, and its satisfaction measurement results are shown in Table 2:

Table 2. Teachers' satisfaction with students' autonomous learning effect

\begin{tabular}{|l|c|}
\hline \multicolumn{1}{|c|}{ Item } & Satisfaction \\
\hline Learning enthusiasm & $81.78 \%$ \\
\hline Enhancement of learning interest & $82.33 \%$ \\
\hline Enhancement of academic performance & $80.92 \%$ \\
\hline Occupational application ability & $83.17 \%$ \\
\hline Overall & $82.05 \%$ \\
\hline
\end{tabular}


It can be seen from the satisfaction results of Table 2, as a whole, after applying POA-based network course teaching mode to higher vocational English teaching, the overall satisfaction of higher vocational teachers on students' autonomous learning effect can reach $82.05 \%$, among which they are most satisfied with students' practical application ability, followed by learning interest, learning enthusiasm. As interest is essential for students' learning improvement, it is believed that the continuously deepened POA-based network course teaching mode will help further enhance higher vocational students' English autonomous learning effect. In the survey, most of the students were satisfied with this new teaching method, mainly because it can help cultivate their autonomous learning ability. Before-class task output can help students realize their weaknesses and most students can conduct autonomic learning based on the learning tasks. Before the class, students conduct selective learning according the input materials provided by teachers, and control learning progress according to their learning level, thus maximizing the absorption of knowledge and greatly cultivating their self-learning ability. In this way, students can memorize what they have learned deeply. This teaching mode closely integrating "input learning" and "output application" is good for students to apply what they have learned to occupational scenarios, thus consolidating their mastery of knowledge and meeting the requirements of the current professional talent market. Meanwhile, the display of output task in the classroom knowledge internalization link can greatly promote the exchange and cooperation exchanges between students. As oral English is an indispensable approach to fulfill tasks, regardless of students' oral English proficiency, they can speak out, discuss, and complete the occupational role tasks assigned by the teacher. In this way, when learning English, no longer limited to listening and watching, students can truly apply what they have learned in occupational practice, and speak out and output.

\section{Conclusions}

Based on POA theory, in accordance with output-driven, input-enabled evaluation principle, according to situation of higher vocational English course teaching and the learning characteristics of higher vocational students, the English course teaching mode was designed to students' autonomous learning. SPOC network teaching mode was also introduced in this paper to provide students with a wealth of teaching resources, and a students' autonomous learning evaluation system was established using AHP method to further promote higher vocational students' English autonomous learning, specifically:

POA teaching mode emphasizes on cultivating students' autonomous learning competence, which is mainly implemented driven by task, enabled by process and evaluation according to results. Teachers play a guiding role, so as to realize students' autonomous learning within the controlled range of teachers.

SPOC teaching mode provides abundant learning resources for students' autonomous learning, so that they can select relevant teaching resources according to their own needs when independently completing tasks, and teachers provide guidance in this 
process. Meanwhile, to ensure that students independently carry out autonomous learning, an independent learning evaluation system was designed in this paper to help students know their weaknesses in their own autonomous learning.

Teaching practice shows that after applying POA-based online course teaching mode to higher vocational English teaching, students' practical application ability, learning interest, and enthusiasm have been improved, and students are also very satisfied with this teaching mode, indicating that the teaching mode is effective.

However, there exist some problems in practical applications of POA-based network course teaching mode, which should be solved one by one so as to utilize the mode effectively the higher vocational English classroom. But due to the limited research, this paper has not conducted further analysis. The results of Table 1 also indicate that the POA-based network course teaching mode still has the possibility of improvement and needs further research in the future.

\section{Acknowledgement}

This research is supporter by the 14th five year plan of Educational Science in Hunan Province (ND214124), Hunan Vocational Education Teaching Reform Research Project (ZJGB2019064) and Key Project of Higher Vocational Education of Hunan Association of educational science researchers (XJKX18A168).

\section{$7 \quad$ References}

[1] Harrison, G.D.A snapshot of early childhood care and education in South Africa: Institutional offerings, challenges and recommendations. South African Journal of Childhood Education, 2020, vol. 10(1), pp. 1-10. https://doi.org/10.4102/sajce.v10i1.797

[2] Steele, D., \& Zhang, R. Enhancement of teacher training: Key to improvement of English education in Japan. Procedia-Social and Behavioral Sciences, 2016, vol. 217, pp. 16-25. https://doi.org/10.1016/j.sbspro.2016.02.007

[3] Wang, Y.L. Bringing in Enterprise Culture to Improve Professional Quality of Higher Vocational Students. Journal of Wuhan Institute of Shipbuilding Technology, 2017, vol. 21(3), pp. 62-64.

[4] Hendriks, R.A., de Jong, P.G., Admiraal, W.F., \& Reinders, M.E. Teaching modes and social-epistemological dimensions in medical massive open online courses: lessons for integration in campus education. Medical teacher, 2019, vol. 41(8), pp. 917-926. https://doi.org/ 10.1080/0142159x.2019.1592140

[5] Li, K.C., \& Wong, B.T.M. Advancing teaching with massive open online courses: a review of case studies. International Journal of Innovation and Learning, 2019, vol. 25(2), pp. 141155. https://doi.org/10.1504/iji1.2019.097660

[6] Mahajan, R., Gupta, K., Kaur, S., et al. Effectiveness of interactive dual-mode online platform for teaching and assessment of students during COVID 19 pandemic: Narrative experience and reflections of undergraduate medical students. Adesh University Journal of Medical Sciences \& Research, 2021, vol. 3(1), pp. 34-40. https://doi.org/10.25259/aujmsr_18 $\underline{2021}$

[7] Han, X.J. Research on College English Blended Teaching Mode Based on Network Platform. Journal of Hubei Open Vocational College, 2021, vol. 12(1), pp. 167-168. 
[8] Sun, R., Zhang, H., Li, J., Zhao, J., \& Dong, P. Assessment-for-Learning Teaching Mode Based on Interactive Teaching Approach in College English. International Journal of Emerging Technologies in Learning, 2020, vol. 15(21), pp. 24-39. https://doi.org/10.3991/ ijet.v15i21.18029

[9] Hu, Y.T. Design of teaching links of thinking map College English writing under the guidance of output oriented method. English Square, 2016, vol. 14(10), pp. 136-137.

[10] James, M.A. Teaching for transfer of second language learning. Language Teaching, 2018, vol. 51(3), pp. 330-348. https://doi.org/10.1017/s0261444818000137

[11] Li, Z. A practical study of "output oriented approach" in English flipped classroom in Higher Vocational Colleges. Chinese Vocational and Technical Education, 2017, vol. 25(31), pp. 88-92.

[12] Wang, Y.K. On Teaching Design of POA-Based Flipped Classroom - A Case Study of "Integrated English"Course. Journal of Anhui University of Technology (Social Sciences Edition), 2019, vol. 36(5), pp. 64-65.

[13] Zhang, Y. A Study of U-Learning Model Based on Production-Oriented Approach:With the Teaching Practice of English for Academic Purposes as an Example. Computer-Assisted Foreign Language Education in China, 2019, vol. 16(3), pp. 110-115.

[14] Xiao, Y. Construction and application of "output oriented approach" in Higher Vocational English Teaching Model -- Taking "health" theme teaching module as an example. Shanxi Youth, 2021, vol. 15(20), pp. 8-10.

\section{Author}

Jinrong Shu is a Lecturer in Hunan Railway Professional Technology College, Zhuzhou City, Hunan Province, China.

Article submitted 2021-11-03. Resubmitted 2021-12-04. Final acceptance 2021-12-06. Final version published as submitted by the author. 